\title{
ResearchOnline@JCU
}

This is the Accepted Version of a paper to be published in the journal Higher Education Research \& Development.

Matthews, Kelly, Belward, Shaun, Coady, Carmel, Rylands, Leanne, and Simbag, Vilma (2015) Curriculum development for quantitative skills in degree programs: a cross-institutional study situated in the life sciences. Higher Education Research \& Development. 35 (3). pp. 545-559.

http://www.herdsa.org.au/?page_id=25 


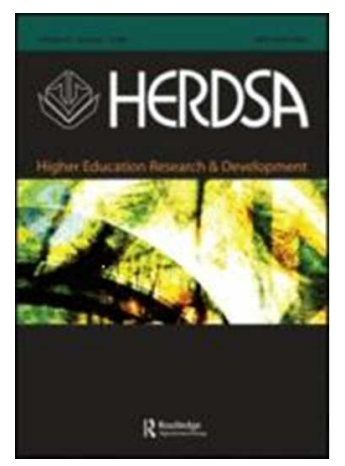

\section{Curriculum development for quantitative skills in degree programs: A cross-institutional study situated in the life sciences}

\begin{tabular}{|r|l|}
\hline Journal: & Higher Education Research \& Development \\
\hline Manuscript ID: & CHER-2014-0005.R3 \\
\hline Manuscript Type: & Article \\
\hline Keywords: & $\begin{array}{l}\text { Curriculum development, Graduate learning outcomes, Quantitative Skills, } \\
\text { Science }\end{array}$ \\
\hline
\end{tabular}

SCHOLARONE

Manuscripts 
Curriculum development for quantitative skills in degree programs:

A cross-institutional study situated in the life sciences

\begin{abstract}
Higher education policies are increasingly focused on graduate learning outcomes, which infer an emphasis on, and deep understanding of, curriculum development across degree programs. As disciplinary influences are known to shape teaching and learning activities, research situated in disciplinary contexts is useful to further an understanding of curriculum development. In the life sciences, several graduate learning outcomes are underpinned by quantitative skills or an ability to apply mathematical and statistical thinking and reasoning. Drawing on data from a national teaching project in Australia that explored quantitative skills in the implemented curricula of 13 life sciences degree programs, this article presents four program level curricular models that emerged from the analysis. The findings are interpreted through the lens of discipline-specific research and general curriculum design theories to further our understanding of curriculum development for graduate learning outcomes. Implications for future research and to guide curriculum development practices in higher education are discussed.
\end{abstract}

\title{
Keywords
}

Curriculum development; graduate learning outcomes; quantitative skills; life sciences

\section{Introduction}

\section{Background and context}

An intention of the Learning and Teaching Academic Standards (LTAS) project in Australia is to drive curricular reform efforts through goal setting activities that articulate graduate learning outcomes. The LTAS project deliberately engaged academic communities through an extensive period of consultation, allowing discipline communities to debate and articulate learning outcomes reflective of their modes of inquiry and academic practice (Ewan, 2010). The implementation of curriculum to achieve stated goals has been left to the institutions and those in the 
disciplines. However, there is a dearth of research on curriculum change and design to achieve graduate learning outcomes in practice (Hubball et al., 2013). The limited research has found that curriculum goal setting has resulted in an approach whereby new units are added to the existing curriculum as the means to build the desired outcome in students (Barrie, Hughes, \& Smith, 2009). This approach, called an 'additive approach', has been found to lead to fragmentation of the curriculum by disconnecting the learning outcome from the disciplinary context and content knowledge of existing units (Barnett \& Coate, 2004; Barrie, 2006). Furthermore, this approach collapses responsibility for implementing curriculum reform to a handful of academics (Barrie et al., 2009), which reduces the involvement and thus likelihood of pedagogical change across the numerous units within a degree program curriculum.

In the sciences, the LTAS project resulted in the science threshold learning outcomes, which provided a foundation 'for articulating and developing the higher education science curriculum, and for improving learning and teaching in science at the university level' (Yates, Jones, \& Kelder, 2011, p. 16). The science outcomes were framed as observable, measureable statements of a product, for example:

Critically analyse and solve scientific problems by:

- collecting, accurately recording, interpreting and drawing conclusions from scientific data (Yates et al., 2011, p. 13).

Skills are not explicitly mentioned in the LTAS statement for science learning outcomes, although the scientific community, like many employers and professional bodies, communicate in terms of 'skills', such as quantitative skills, which underpin the science graduate learning outcomes [removed for blind review].

The application of mathematics and statistics is unarguably necessary in the sciences. These applications, which are often referred to as quantitative skills, are increasingly being cited as an essential learning outcome of science degree programs with a particularly emphasis on the life sciences (AAAS, 2011; AAMC, 2009; Brown, 2009; [removed for blind review]; NRC, 2003, 2009). Inherently interdisciplinary, quantitative skills are based on a foundation of mathematical and statistical knowledge which can then be applied in scientific contexts to solve numeric problems, design scientific experiments, recognise patterns, develop models, describe and interpret data, draw logical conclusions and make predictions. The intent of 
articulating graduate learning outcomes, like quantitative skills, is to emphasise that students should develop them across the degree program. The curriculum environments that foster such learning outcomes are ones that design numerous scaffolded opportunities for students to learn and demonstrate their learning across an extended period of time/years (Yorke \& Knight, 2006).

\section{Contribution and purpose of the study}

The intended contribution of this paper is to offer insight into discipline specific curriculum design through a cross institutional comparison of life science degree programs that identified quantitative skills as a graduate learning outcome. This article is framed within a larger project and specifically investigates the design of curriculum to build quantitative skills across life sciences degree programs.

\section{Methodology}

This article draws on data collected through a two-year research project, [removed for blind review]. To explore the design of life sciences curriculum to build a graduate learning outcome, a qualitative case study methodology recommended by Yin (2008) was adopted. Qualitative studies are grounded within their context to present the holistic picture of the phenomena being studied (Creswell, 2012). Common in education, in-depth case studies are used as a device to explore and illustrate a problem or issue, usually one that is not well understood (Merriam, 1988; Yin, 2008). The unit of analysis is the degree program curriculum, situated within the science disciplinary context of each university studied, focused on the critical pathway of units requiring quantitative skills. We adapted a conception of curriculum as a progressive series of units for the purposes of comparative analysis (Fraser \& Bosanquet, 2006) with a view on the 'implemented curriculum' as espoused by academics.

To explore science curriculum at the program level meaningfully, the project focused on majors within science undergraduate degree programs. Life sciences majors were selected for two reasons. First, the majority of undergraduate science students in Australia are enrolled in life sciences majors (Chubb, 2012). Second, the life sciences have been identified as weak in developing quantitative skills (NRC, 2003, 2009). 


\section{Selecting case studies}

A multiple case design with purposeful sampling was utilised (Creswell, 2012). The sampling strategy was to select those institutions that were actively attempting to reform their science curriculum with quantitative skills as an intended learning outcome. The Executive Director of Australian Council of Deans of Science (ACDS) was consulted to identify potential institutions undergoing review and reform with quantitative skills as a focus. The ACDS includes all science deans of Australian universities with participants recruited at their Annual General Meeting. Two large, public universities in the United States of America that were well known for their efforts to build quantitative skills were identified in this process. Their inclusion was opportunistic and they were viewed as comparable to Australian universities. Table 1 details the 13 institutions involved in the study. 
Table 1: Participant information for each university case study and interviewees.

\begin{tabular}{|c|c|c|c|c|c|c|c|c|}
\hline \multirow[t]{2}{*}{ University } & \multicolumn{5}{|c|}{ Case Study University Information } & \multicolumn{3}{|c|}{ Interviewee Information } \\
\hline & Country & Founded & Type & $\begin{array}{l}\text { Number of } \\
\text { staff }(\text { FTE })^{*}\end{array}$ & $\begin{array}{l}\text { Number of } \\
\text { students }\end{array}$ & $\mathrm{ADA}^{* *}$ & $\begin{array}{l}\text { Teaching } \\
\text { academic }\end{array}$ & $\begin{array}{c}\text { Total } \\
\text { participants }\end{array}$ \\
\hline Case Study 1 & Australia & 1986 & public; multicampus: regional & 3020 & 44990 & $1 \sim$ & 0 & 1 \\
\hline Case Study 2 & Australia & 1970 & public; multicampus; regional & 1632 & 15756 & 1 & 3 & 4 \\
\hline Case Study 3 & USA & 1908 & public; regional & 1319 & 19927 & $4 \sim$ & 6 & 10 \\
\hline Case Study 4 & Australia & 1967 & public; multicampus; metropolitan & 3011 & 25744 & 1 & 3 & 4 \\
\hline Case Study 5 & Australia & 1964 & public; metropolitan & $N / A^{* \wedge}$ & 37132 & 1 & $2^{\wedge}$ & 3 \\
\hline Case Study 6 & Australia & 1958 & public; multicampus; metropolitan; research-intensive & 8172 & 55000 & 1 & 2 & 3 \\
\hline Case Study 7 & Australia & 1991 & public; metropolitan & 4065 & 39919 & 1 & 3 & 4 \\
\hline Case Study 8 & USA & 1856 & public; multicampus; metropolitan; research-intensive & 4248 & 37631 & $2 \sim$ & 1 & 3 \\
\hline $\begin{array}{l}\text { Case Study 9a } \\
\text { Case Study 9b }\end{array}$ & Australia & 1853 & public; multicampus; metropolitan; research-intensive & 7325 & 35909 & 1 & 2 & 3 \\
\hline Case Study 11 & Australia & 1850 & public; multicampus; metropolitan; research-intensive & 6664 & 47775 & 1 & $1^{\wedge}$ & 2 \\
\hline Case Study 12 & Australia & 1989 & public; multicampus; regional & 5102 & 37426 & 1 & 2 & 3 \\
\hline Case Study 13 & Australia & 1951 & public; multicampus; regional & 1765 & 26008 & 1 & 4 & 5 \\
\hline
\end{tabular}

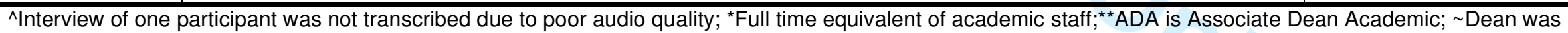
interviewed; ${ }^{\wedge} \mathrm{N} / \mathrm{A}$ is Data not available 


\section{Data Collection}

Semi-structured interviews were conducted to gather insight into the structure of the degree program along with a simple visual tool to represent the curriculum as units at each year level across the degree program. The Associate Dean Academic (ADA) (or equivalent) was emailed a formal invitation to participate, they were chosen because of their role in overseeing science degree programs. All ADAs confirmed that quantitative skills was an aim all of their science degree programs and agreed to participate in the study. The ADAs then identified mathematics and science academics in charge of, or teaching into, at least one unit with quantitative components in the degree program to participate in the interviews. Table 1 gives numbers and roles of interviewees at each of the participating universities under "Interviewee Information".

The ADAs were interviewed at all universities and also a varying number of teaching academics interviewed depending on who was identified by the ADA. In some instances, groups of academics were interviewed together whilst other interviews were conducted individually; this was decided by the preference of the participants. Case study 3 had far more interviewees than any other university, which is explained by ongoing projects to develop quantitative skills across the curriculum dating back 10 years. In addition, the visit by overseas colleagues was viewed with enthusiasm and so attracted many academics to group interview sessions.

The same interview guide was used for ADAs and teaching academics although it was acknowledged that interviewees might not be able to answer all the questions pertaining to the degree program curriculum. Interviews were audio recorded, transcribed and sent to interviewees for verification. The definition of quantitative skills was explicitly stated at the start of all the interviews to better ensure a shared meaning: the application of mathematical and statistical thinking and reasoning in the context of science. This definition implies that quantitative skills build on mathematical and statistical knowledge, while inferring that quantitative skills are more than a mathematics or statistics unit. All interviewees were asked to identify units where quantitative skills were taught across a major at their university. Two criteria were articulated and applied during the development of the case studies to identify quantitative skills units in the degree program: 
(1) quantitative skills are substantially taught and assessed; and

(2) The unit is compulsory or highly recommended whereby the majority of students in the major complete the unit.

Upper level units with substantial quantitative skills were discussed, however, unless the majority of the students in the major completed the unit, it was not included in the analysis. A critical pathway is similar to the "pathways' and 'routes' typically taken by students completing a particular major (Yorke \& Knight, 2006). Drawing on multiple academics within the degree program strengthened the validity of the quantitative skills critical pathways identified for each case study.

\section{Participants}

Fourteen case studies across 13 universities were initially selected. Table 1 displays information about each case study university. By the time that data was collected, processed and translated into a case study, one university (case study 7 , Table 1) had undergone a substantial restructure and subsequent curriculum reform in science that rendered its data irrelevant. Thus, this case study was not included for the purposes of this article. Another university (case study 9, Table 1) elected to have two science degree programs included in the study, a Bachelor of Science and a Bachelor of Biomedical Science. The two degrees shared many units and a common focus on quantitative skills but were run from separate organisational units. Finally, only one academic was interviewed at one university (case study 1, Table 1), which was the Dean, who specifically requested to participate. Thus, the single perspective of the Dean limits this case study.

Ultimately, 13 case studies from 12 universities were included in this study. Data were gathered from 48 academics through face-to-face, semistructured interviews and document analysis drawn largely from university websites.

\section{Analysis}

All researchers (authors) participated in data analysis. The researchers drew on the interview data, institutional websites and program documentation that informed the development of the case studies. This process involved corresponding with the 
interviewees as needed to clarify inconsistencies between interviewees within the same institutions, and between interview information and document information. Then the case studies were made available to the interviewees for verification. All interviewees agreed to share a public version of their case studies, as a resource to others, in a project report [removed for blind review] and on the project website. This article draws on those case studies but focuses specifically on the design of the 'implemented curriculum'.

Our analysis focused on these 13 curricular structures that identified the critical pathway for student development of quantitative skills (Yorke and Knight, 2006) within an iterative, comparative case study approach that allowed themes, patterns and models to emerge from the analysis (Strauss and Corbin, 1997; Kember and Ginns; 2012). Specific to the case study approach, Yin (2008) suggests a comparative cross-case analysis technique where a selected framework is applied to cases with data displayed visually or in tables to identify patterns, similarities and differences. To represent and compare the critical pathway across each degree program, a simple visual curriculum map was employed (see Figure 1) along with the use of data tables. The visual map represents the eight units per year over three years curricula that are typical of a science degree program. Given the flexible nature of science degree programs, quantitative skills units were identified by year level, not semester, in the visual maps. Mapping learning outcomes, as a table, matrix or visual structure, is a widely utilised strategy to represent the implemented curriculum (Ewell, 2013).

Four of the authors conducted the comparative analysis of the visual structures, each having a set of the 13 curricular structures representing the 13 degree programs included in the study. First, the authors conducted the analysis individually, documenting the emerging patterns and trends across program structures. Next, the authors compared findings, and continued through an iterative process of comparing and discussing potential patterns as a collective. 
Figure 1: Example of visual curricular map developed for each case study to represent the implemented quantitative skills critical pathway across the curriculum.

\section{Results}

To investigate the design of curriculum to build quantitative skills across life sciences degree programs, data on the 'implemented curriculum' were drawn from 13 case studies. Appendix 1 presents a broad overview of each case study. This overview shows the life sciences major and institutional contexts for the 'implemented curriculum', including institutional factors for change, vision for quantitative skills as documented in institutional or program level graduate outcomes, models of the 'implemented curriculum', and information on evidence of curriculum change through evaluation.

\section{Four emerging curricular models}

Analysis by year level highlighted an overall trend of more structure at $1^{\text {st }}$ year levels allowing for quantitative skills units to be more visible within the 
quantitative skills critical pathway, with less structure identifiable as students progressed into $2^{\text {nd }}$ and $3^{\text {rd }}$ year levels. Overall, the comparative analysis indicated that quantitative skills were not substantially designed or developed in undergraduate science curricula in a manner that is easily identifiable. Figure 1 is typical in highlighting the 'white space' evident in the 13 case study curricular structures.

Analysis across the entire three/four years of the 13 science curricula revealed no patterns for how quantitative skills were designed across the programs. Analysis by year level, however, led to the categorisation of four discrete curriculum models, which are discussed below and displayed in Appendix 1 and Figure 2.

\section{Unit Model}

The unit model of curricular design was characterised by dedicated quantitative skills units, which were compulsory or highly recommended. While the majority of quantitative skills units were taught by a single discipline (five of the eight), three units were employing a cross disciplinary approach whereby mathematicians/statisticians and life scientists were developing, designing and teaching a single quantitative skills unit together (case studies 2, 4, 10; Appendix 1). In Figure 1 , the $2^{\text {nd }}$ year features the unit model with a single, dedicated quantitative skills unit as the only identifiable unit teaching and assessing quantitative skills.

\section{Embed Model}

The embed model is characterised by modules to build quantitative skills being incorporated, or embedded, into disciplinary based units. Again, the analysis showed that the majority of teaching of quantitative skills embedded modules was done within the context of a single discipline with only two instances of mathematicians or statisticians teaching the quantitative skills module within the discipline based unit (both in case study 10; Appendix 1). This curricular model for building quantitative skills is the most common model for $3^{\text {rd }}$ year science programs studied, although it is also quite prevalent at the $2^{\text {nd }}$ year level. In $1^{\text {st }}$ year, only one science curriculum was categorised as an embed model (case study 
13; Appendix 1).

\section{Hybrid (Unit+Embed) Model}

The hybrid model is evident where curricula are designed with both features of the unit and the embed models in a given year level (represented in $1^{\text {st }}$ year of Figure 1). This curricular model to build quantitative skills was only evident in $1^{\text {st }}$ year. The most common implementation of the hybrid model (five of the eight) featured a quantitative skills unit taught by the mathematics/statistics department with modules embedded in disciplinary based units and taught by the discipline-based academics.

\section{Silent Model}

In several instances quantitative skills could not be identified as being taught and assessed within the critical pathway for the major. The silent model refers to a lack of a curricular approach to develop quantitative skills, where no unit of study in the year level teaches quantitative skills, whether embedded or as a dedicated unit. No case studied featured the silent model at $1^{\text {st }}$ year. In three of the $2^{\text {nd }}$ year curricula quantitative skills could not be identified. Five of the 13 case studies displayed no quantitative skills in the final year of study.

\section{Quantitative skills across the curriculum}

Across the case studies, institutions were employing differing models at each year level, such that various combinations of curricular models were evident at a single university at $1^{\text {st }}, 2^{\text {nd }}$ and $3^{\text {rd }}$ years, as suggested in Figure 1 . Figure 2 offers a quantitative view of the findings, revealing the percentage for each model employed across the year levels for the 13 case studies. For example, at $1^{\text {st }}$ year, the majority of curricula (61\%) employed a hybrid model with this model not evident at the $2^{\text {nd }}$ or $3^{\text {rd }}$ year levels. The silent model, not evident at $1^{\text {st }}$ year, is most prevalent at $2^{\text {nd }}$ year $(31 \%)$ with a decline at $3^{\text {rd }}$ year $(23 \%)$. To get a picture of the amount of quantitative skills identified across the curriculum, further analysis of quantitative skills units and embedded modules were conducted. Typical of Australian universities, a science degree program is three years with 8 units per year. Thus, students complete 24 units. The average curriculum included 4.75 quantitative skills units (combination of dedicated units and embedded 
modules within units), indicating that quantitative skills learning activities comprise $20 \%$ of the science curriculum [removed for blind review]. The average amount of quantitative skills in the science curriculum, combined with the curricular models showing the silent model at the $2^{\text {nd }}$ and $3^{\text {rd }}$ year levels, are evidence of the limited visibility of quantitative skills overall and the declining visibility of quantitative skills from $1^{\text {st }}$ to $3^{\text {rd }}$ years.

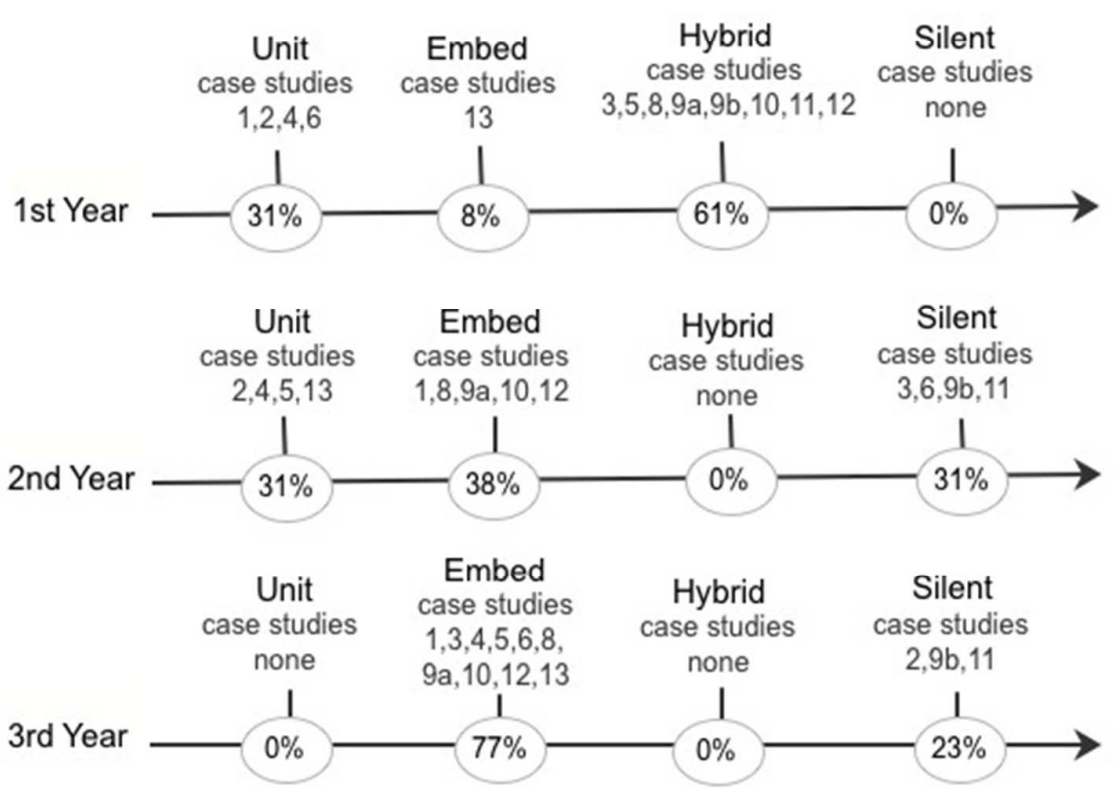

Figure 2: Percentage of respondents who mentioned quantitative skills. Case study numbers align to Table 1 and Appendix 1.

\section{Discussion}

It is widely recognised that the greatest scope for curriculum change is at the discipline level. Instances where changes are unfolding around learning outcomes are a consequence of changing disciplinary practices and inquiry, and not of institutional level articulation of attributes according to Barnett (2000b). Fullan (2007) suggests change occurs when learning outcomes reflect or align with the changes in the discipline. Our study was deliberately situated within the discipline context of the life sciences, focused on a graduate learning outcome agreed upon by that discipline community. The case studies represent universities undergoing curriculum reform in the sciences to build students' quantitative skills. While 
potential theoretical barriers to curriculum reform were reduced, the 13 curricula investigated in this study revealed a limited presence of quantitative skills. Given that curriculum environments that foster graduate learning outcomes are ones that design numerous scaffolded opportunities for students to learn and demonstrate their learning across an extended period of time/years (Yorke \& Knight, 2006), the current study suggests that there are insufficient learning opportunities for students to adequately build their quantitative skills across the degree program.

\section{Interpreting the four curricular models within the disciplinary context}

Undergraduate science education tends to be modularised and fragmented into discrete disciplinary units (Tagg and Barr, 1995; Barnett and Coates, 2005). Thus, the unit model implemented in eight of the case studies is a typical additive approach to build a graduate learning outcome. Adding a unit, often separated from application to the disciplinary context, offers a quick-fix appeal to address learning outcome requirements (Barrie et al, 2009). The disconnection of knowledge from skills or application, typical of science education (Barnett \& Coate, 2004), was evident in the case studies. Potentially, the unit model inhibits students' ability to then transfer quantitative skills to scientific context. Some studies have highlighted the inability of students to transfer mathematical knowledge to science contexts (Britton, New, Sharma, \& Yardley, 2005; Tariq, 2008). In this study there were three case studies where implementation of science curriculum to build quantitative skills reflected awareness of this potential disconnect with the inclusion of purposely developed, cross-disciplinary quantitative skills units. However, the majority of curriculum included units at $1^{\text {st }}$ year with a goal to bring students up to a particular standard in mathematics in response to the diversity of mathematical prior knowledge held by entering students.

The embed model offers the opportunity to integrate quantitative skills in the context of science, suggesting greater translation across disciplinary domains as skills are linked to content knowledge. However, the majority of embedded quantitative skills modules were conducted in laboratory classes, which have come under scrutiny for being separated from the content knowledge emphasised in lectures and on examinations (Rice, Thomas, \& O'Toole, 2009). Although the embed model potentially facilitates translation of quantitative skills in scientific 
context, most academics interviewed discussed embedding quantitative skills as a remedial approach whereby the teaching of quantitative skills was done alongside but separately from the scientific context.

The hybrid model suggests that students have multiple quantitative skills learning opportunities in dedicated quantitative skills units and quantitative skills embedded modules contextualised in discipline contexts at a given year level. Thus, the hybrid model is the closest model to that of Yorke \& Knight's (2006) notion of curriculum development for learning outcomes, whereby students have multiple, scaffolded learning opportunities to develop the desired outcome over an extended period of time. This approach was only evident at $1^{\text {st }}$ year in eight of the case studies.

While all the interviewees in our study agreed that quantitative skills were an essential learning outcome, more dominant disciplinary factors beyond their beliefs about teaching and curriculum motivated their actions. Unlike professional degree programs, most science disciplines have not had the external drivers via professional accreditation bodies to influence curriculum development around stated graduate learning outcomes. Furthermore, the pressures to excel in research combined with the rewards of research success and the time consuming and costly nature of scientific research, inhibit a disciplinary focus on the matter of teaching and curriculum development (Hora, 2012). Therefore, the silent model, evident in five of the case studies and the overall low visible presence of quantitative skills across the 13 curricula, is perhaps unsurprising although disconcerting.

\section{Within discipline qualitative variation in curriculum design}

Non-domain specific research in curriculum development to build graduate attributes provided heuristic insight and guidance for this study. However, interpretation without disciplinary contextualisation would have been incomplete or potentially misleading. For example, two domain-independent studies hypothesised that discipline communities would share an understanding of graduate learning outcomes and curriculum (Barrie, 2006; Fraser \& Bosanquet, 2006). However, our project revealed within discipline differences of how science curriculum in the life sciences was designed to build quantitative skills. While we were able to extrapolate four models of quantitative skills in science curriculum at 
year levels, there was no overarching or common approach to how science curricula were designed across the 13 degree programs included in this study.

Although quantitative skills were defined at the start of each interview as the application of mathematical and statistical thinking and reasoning in science contexts, interviewees held different ideas about what quantitative skills were needed in the life sciences. As suggested by domain-independent research (Barrie, 2006; Fraser \& Bosanquet, 2006), there was a difference in beliefs about how curriculum to build quantitative skills should be designed between scientists and mathematicians involved in this study. Furthermore, ideas about what specific quantitative skills needed for life science students also varied by science and mathematics disciplines [removed for blind review]. However, beliefs about how to design curriculum and what specific quantitative skills were needed also varied within disciplines. The within discipline qualitative variation in what quantitative skills are needed could be one factor explaining the variation in curriculum design to build quantitative skills across the 13 curricula.

\section{Implications}

Efforts to map curricula have emerged with research centred on mapping numerous and generic outcomes across many disciplines (Tariq et al., 2004; Spencer, Riddle and Knewstubb, 2012). Mapping learning outcomes across the curriculum offers some information on the design of the curriculum in terms of what is implemented (Spencer et al., 2012). Much of the empirical literature on curriculum and achieving learning outcomes in higher education has centred on mapping as a product to demonstrate or prove that graduate outcomes are being implemented, as opposed to the mapping as a process to create collegial conversation on student learning and curricular design (Sumsion and Goodfellow, 2004). Engaging academics in collegial conversations, which is precisely the type of activity that Barnett (2000b) argues is missing in higher education, can result in forums for academics to discuss curricular issues and plan for curriculum development that builds graduate learning outcomes.

We argue that the products of mapping can offer insight into curricular design which could further the sector's influence on curricula planning and approaches, as opposed to simply documenting what is. Our study uses curricular maps as a source of insight and data, which we analysed to identify patterns and 
emerging models of curricular design. Our curricular models contribute a tangible framework to engage academics in considering their beliefs about curricula, and challenge notions of how curricula should be designed, instead of simply being engaged in mapping of current practice.

While it is acknowledged that curriculum at the level of the degree program involves a range of stakeholders and is implemented locally within disciplinary contexts (Hubball et al., 2013), much of the research on curriculum and graduate learning outcomes has focused on the views of individual academics isolated from the socio-cultural context of the degree program curriculum (Barrie, 2006, 2007; Fraser \& Bosanquet, 2006). Furthermore, guides to curriculum development in higher education, while sparse, tend to focus on leadership for curriculum development or that of individuals' enacting curriculum (Lattuca \& Stark, 2011; Oliver, 2013), neglecting curriculum at the level of the degree program. Considered from the perspective of building a graduate learning outcome, a gap in curriculum development research in higher education arises. That is, research whereby curriculum is conceived and implemented by numerous individuals in what should be a socially derived set of intentions and activities arising from collective beliefs and shared understanding. Thus, research into the development of shared ideas of curriculum and learning outcomes, how they are formed, maintained and enacted by groups of academics, should be a future focus of research.

\section{Limitations}

These case studies offer snapshots of the curriculum and are limited by the perspectives of those academics we interviewed. We caution readers in generalising these findings to science curriculum more broadly as the sampling was purposeful and not intended to be representative of science degree programs. Attempting to capture curriculum for the purpose of this study was complicated and pragmatic decisions were made that should be considered. First, we limited our scope to the formal, assessed curriculum, which excluded informal, nonassessed learning activities. Second, program level curriculum involves many people and we were not able to interview all people involved. Third, we documented the curriculum from the perspective of academics as they selfreported curricular activities. 


\section{Conclusion}

This article focused on a tangible learning outcome (quantitative skills) within a disciplinary context (life sciences) to explore how 13 curricula are designed to develop graduate learning outcomes. While year-level curricular models emerged, the overall findings indicated the limited visibility of quantitative skills and little similarity in how they were developed across the 13 science curricula. These empirical findings document within discipline differences of curriculum development, which offers a new contribution to the curriculum development literature that has emphasised between discipline differences.

As higher education policies focus on graduate learning outcomes, there is a need for curriculum research into learning outcomes at the level of the degree program. First, this study contributes a robust, repeatable procedure of inquiry for curriculum development research into graduate learning outcomes. Second, this article offers baseline research into how a graduate learning outcome is developed in unstructured degree programs. Third, models of curriculum development derived from empirical analysis are provided that contribute heuristic models from which to consider other curricular approaches to build a learning outcome.

\section{Acknowledgements}

The anonymous reviewers and editor contributed substantially to the enhancement of this manuscript. Support for this publication has been provided by the Australian Government Office for Learning and Teaching. The views expressed in this publication do not necessarily reflect the views of the Australian Government Office for Learning and Teaching. Aspects of the study methodology and emergent curricular models are based on the [removed for blind review] project report [removed for blind review]. 
Appendix 1

\begin{tabular}{|c|c|c|c|c|c|c|c|c|c|c|}
\hline \multicolumn{2}{|c|}{$\begin{array}{l}\text { Case Study } \\
\text { Information }\end{array}$} & \multicolumn{2}{|c|}{ Curriculum change factors } & \multirow{2}{*}{$\begin{array}{c}\text { Vision } \\
\text { Level of } \\
\text { QS } \\
\text { Learning } \\
\text { Outcomes }\end{array}$} & \multicolumn{5}{|c|}{ Implementation of curriculum } & \multirow{2}{*}{$\begin{array}{c}\text { Evaluation } \\
\text { Program Level } \\
\text { QS Evaluation }\end{array}$} \\
\hline $\begin{array}{l}\text { Case } \\
\text { Study* }\end{array}$ & Major ${ }^{\star \star}$ & $\begin{array}{l}\text { Curriculum } \\
\text { Review }\end{array}$ & Review Phase & & $\begin{array}{c}\text { Mathematics } \\
\text { Pre- } \\
\text { requisite }\end{array}$ & $\begin{array}{c}\text { 1st } \\
\text { Year } \\
\text { Model }\end{array}$ & $\begin{array}{c}\text { 2nd } \\
\text { Year } \\
\text { Model }\end{array}$ & $\begin{array}{l}\text { 3rd } \\
\text { Year } \\
\text { Model }\end{array}$ & $\begin{array}{c}\text { Extra } \\
\text { Curricular QS }\end{array}$ & \\
\hline 1 & $\begin{array}{c}\text { Overview of } \\
\text { BSc }\end{array}$ & $\begin{array}{l}\text { University-wide } \\
\text { program review }\end{array}$ & $\begin{array}{c}\text { Early } \\
\text { implementation }\end{array}$ & Major & $\begin{array}{l}\text { Selected } \\
\text { majors }\end{array}$ & Unit & Embed & Embed & None & No \\
\hline 2 & $\begin{array}{l}\text { Marine } \\
\text { Biology }\end{array}$ & $\begin{array}{l}\text { University-wide } \\
\text { program review }\end{array}$ & $\begin{array}{c}\text { Early } \\
\text { implementation }\end{array}$ & Unit & Yes & Unit & Unit & Silent & None & No \\
\hline 3 & Biology & $\begin{array}{c}\text { University cycle of } \\
\text { program review }\end{array}$ & Evaluation & Major & Yes & Hybrid & Silent & Embed & $\begin{array}{c}\text { Research } \\
\text { Experiences }\end{array}$ & Yes \\
\hline 4 & $\begin{array}{l}\text { Biological } \\
\text { Sciences }\end{array}$ & $\begin{array}{l}\text { University-wide } \\
\text { program review }\end{array}$ & $\begin{array}{c}\text { Early } \\
\text { implementation }\end{array}$ & Faculty & Yes & Unit & Unit & Embed & $\begin{array}{c}\text { Mathematics } \\
\text { Learning Centre }\end{array}$ & No \\
\hline 5 & $\begin{array}{l}\text { Biological } \\
\text { Sciences }\end{array}$ & $\begin{array}{l}\text { University-wide } \\
\text { program review }\end{array}$ & $\begin{array}{c}\text { Early } \\
\text { implementation }\end{array}$ & Major & Assumed^ & Hybrid & Unit & Embed & $\begin{array}{c}\text { Mathematics } \\
\text { Learning Centre }\end{array}$ & No \\
\hline 6 & $\begin{array}{l}\text { Biological } \\
\text { Sciences }\end{array}$ & $\begin{array}{c}\text { University cycle of } \\
\text { program review }\end{array}$ & $\begin{array}{l}\text { Late } \\
\text { implementation }\end{array}$ & $\begin{array}{l}\text { Degree } \\
\text { program }\end{array}$ & No & Unit & Silent & Embed & $\begin{array}{c}\text { Mathematics } \\
\text { Learning Centre }\end{array}$ & Yes \\
\hline 8 & $\begin{array}{l}\text { Biological } \\
\text { Sciences }\end{array}$ & $\begin{array}{l}\text { University-wide } \\
\text { program review }\end{array}$ & $\begin{array}{l}\text { Late } \\
\text { implementation }\end{array}$ & Major & Yes & Hybrid & Embed & Embed & Online Modules & No \\
\hline $9 a$ & $\begin{array}{l}\text { Biological } \\
\text { Sciences }\end{array}$ & $\begin{array}{l}\text { University-wide } \\
\text { program review }\end{array}$ & $\begin{array}{c}\text { Late } \\
\text { implementation }\end{array}$ & $\begin{array}{l}\text { Degree } \\
\text { program }\end{array}$ & Yes & Hybrid & Embed & Embed & $\begin{array}{c}\text { Mathematics } \\
\text { Learning Centre }\end{array}$ & No \\
\hline $9 b$ & $\begin{array}{c}\text { Bachelor of } \\
\text { Biomedicine }\end{array}$ & $\begin{array}{l}\text { University-wide } \\
\text { program review }\end{array}$ & $\begin{array}{l}\text { Late } \\
\text { implementation }\end{array}$ & $\begin{array}{l}\text { Degree } \\
\text { program }\end{array}$ & No & Hybrid & Silent & Silent & $\begin{array}{c}\text { Mathematics } \\
\text { Learning Centre }\end{array}$ & No \\
\hline 10 & $\begin{array}{l}\text { Biomedical } \\
\text { Science }\end{array}$ & $\begin{array}{c}\text { University cycle of } \\
\text { program review }\end{array}$ & $\begin{array}{c}\text { Late } \\
\text { implementation }\end{array}$ & $\begin{array}{l}\text { Degree } \\
\text { program }\end{array}$ & Yes & Hybrid & Embed & Embed & $\begin{array}{c}\text { Mathematics } \\
\text { Learning Centre }\end{array}$ & Yes \\
\hline 11 & $\begin{array}{l}\text { Biological } \\
\text { Sciences }\end{array}$ & $\begin{array}{l}\text { University-wide } \\
\text { program review }\end{array}$ & $\begin{array}{l}\text { Late } \\
\text { implementation }\end{array}$ & Faculty & No & Hybrid & Silent & Silent & $\begin{array}{c}\text { Mathematics } \\
\text { Learning Centre }\end{array}$ & No \\
\hline 12 & Chemistry & $\begin{array}{l}\text { Institutional } \\
\text { restructure }\end{array}$ & Vision & $\begin{array}{l}\text { Degree } \\
\text { program }\end{array}$ & No & Hybrid & Embed & Embed & $\begin{array}{c}\text { Mathematics } \\
\text { Learning Centre }\end{array}$ & No \\
\hline 13 & $\begin{array}{l}\text { Biological } \\
\text { Sciences }\end{array}$ & $\begin{array}{l}\text { University cycle of } \\
\text { program review }\end{array}$ & $\begin{array}{c}\text { Late } \\
\text { implementation }\end{array}$ & $\begin{array}{l}\text { Degree } \\
\text { program }\end{array}$ & Assumed $^{\wedge}$ & Embed & Unit & Embed & None & No \\
\hline
\end{tabular}

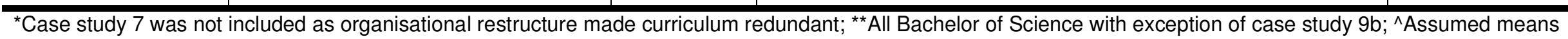

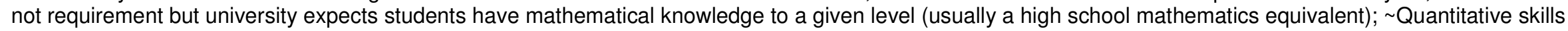

URL: http://mc.manuscriptcentral.com/cher Email: diana.herd@hotmail.co.nz 


\section{References}

AAAS, Amercian Association for the Advancement of Science. (2011). Vision and change in undergraduate biology education: A call to action. In C. A. Brewer \& D. Smith (Eds.). Washington, DC.

AAMC, Amercian Association of Medical Colleges. (2009). Scientific foundations for future physicians. Washington, DC.

Barnett, R., \& Coate, K. (2004). Engaging the curriculum in higher education: Open University Press.

Barrie, S. (2006). Understanding what we mean by the generic attributes of graduates. Higher Education, 51(2), 215-241.

Barrie, S. (2007). A conceptual framework for the teaching and learning of generic graduate attributes. Studies in Higher Education, 32(4), 439-458.

Barrie, S., Hughes, C., \& Smith, C. D. (2009). The national graduate attributes project: Integration and assessment of graduate attributes in curriculum. Sydney, Australia: Australian Learning and Teaching Council.

Britton, S., New, P. B., Sharma, M. D., \& Yardley, D. (2005). A case study of the transfer of mathematics skills by university students. International Journal of Mathematics Education in Science and Technology, 36(1), 1-13.

Brown, G. (2009). Review of education in mathematics, data science and quantitative disciplines: Report to the Group of Eight Universities. Canberra.

Chubb, I. (2012). Health of Australian Science: Office of the Chief Scientist. Canberra: Australian Government.

Creswell, J. W. (2012). Qualitative inquiry and research design: Choosing among five approaches: SAGE Publications, Incorporated.

Ewan, C. (2010). Disciplines setting standards: The learning and teaching academic standards (ltas) project. Quality in Uncertain Times, 1.

Ewell, P. T. (2013). The Lumina Degree Qualifications Profile (DQP): Implications for assessment. National Institute for Learning Outcomes Assessment.

Fraser, S. P., \& Bosanquet, A. M. (2006). The curriculum? That's just a unit outline, isn't it? Studies in Higher Education, 31(03), 269-284.

Hora, M. T. (2012). Organizational factors and instructional decision-making: A cognitive perspective. The Review of Higher Education, 35(2), 207-235.

Hubball, H., Marion, P. L., \& Clarke, A. (2013). SoTL Inquiry in Broader Curricular and Institutional Contexts: Theoretical Underpinnings and Emerging Trends. Teaching \& Learning Inquiry: The ISSOTL Journal, 1(1), 41-57.

Lattuca, L. R., \& Stark, J. S. (2011). Shaping the college curriculum: Academic plans in context: Jossey-Bass.

[removed for blind review]

[removed for blind review]

Merriam, S. B. (1988). Case study research in education: A qualitative approach: Jossey-Bass.

NRC, National Research Council. (2003). BIO2010: Transforming undergraduate education for future research biologists. Washington DC.: National Academies Press.

NRC. (2009). A new biology for the 21st century. Washington, D.C.: National Research Council of the National Academies.

Oliver, B. (2013). Graduate attributes as a focus for institution-wide curriculum renewal: innovations and challenges. Higher Education Research \& Development(ahead-of-print), 1-14. 
Rice, J. W., Thomas, S. M., \& O'Toole, P. (2009). Tertiary science education in the 21st century Melbourne: Australian Council of Deans of Science.

[removed for blind review]

Tariq, V. N. (2008). Defining the problem: mathematical errors and misconceptions exhibited by first-year bioscience undergraduates. International Journal of Mathematical Education in Science and Technology, 39(7), 889-904.

Yates, B., Jones, S., \& Kelder, J. (2011). Learning and Teaching Academic Standards Project: Science. Canberra, Australia: Australian Learning and Teaching Council.

Yin, R. K. (2008). Case study research: Design and methods (Vol. 5): Sage Publications, Incorporated.

Yorke, M., \& Knight, P. T. (2006). Curricula for Economic and Social Gain. Higher Education, 51(4), 565-588. 